\title{
Police Operational Competence and Performance of Graduates of Regional Training Center
}

\author{
Jimmy P. Laguyo ${ }^{1}$ and Merlita V. Caelian ${ }^{2}$ \\ ${ }^{1}$ Regional Training Center 6, Bacolod City, Philippines \\ 2University of Negros Occidental-Recoletos, Bacolod City, Philippines
}

\author{
Article history \\ Submitted: 12 July 2020 \\ Revised: 27 October 2020 \\ Accepted: 16 November 2020 \\ Keywords \\ Public Administration \\ Competence \\ Performance \\ Police Training \\ Descriptive-Correlational \\ Negros Occidental \\ Philippines
}

Introduction. Police operational competence and performance are parameters for police efficiency and effectiveness. An assessment of competence can help the organization achieve excellence in operations. Today, the country is facing more significant challenges in preserving peace and order. The country has to undergo internal changes and transformation that can only be attained through effective training programs. Hence, the paper assessed the level of operational competence and performance of graduates of RTC6 assigned in city police stations in Negros Occidental in the areas of traffic, patrol, and investigation operations assessed by their supervisors when graduates were taken as a whole and grouped according to rank, length of service, and city class. Likewise, the study sought to investigate the relationship between operational competence and performance.

Methods. Descriptive, comparative, and correlational research was used to describe the level of operational competence and performance of the police graduates. Forty supervisors of the one hundred graduates participated in the study. The data were gathered using a researcher-made questionnaire based on the Police Training Manual for Field Training on competence and the Civil Service Commission Evaluation on performance. Data were analyzed using Mean, Standard Deviation, Independent Sample t-test, and Pearson Product-Moment Correlation.

Results. The findings revealed that police graduates of RTC6 are generally "competent," which means that the graduates demonstrate more than adequate knowledge, skills, and abilities. Of the three domains, traffic operation rated the highest while investigation rated the lowest. Police graduates are also rated competent in patrol operations. Police Commissioned Officers (PCOs) provided higher ratings than Police Non-Commissioned Officers (PNCOs) in the three domains. In terms of rank, patrolmen were rated higher than police corporals, those who have rendered short service were rated higher than those who were longer in the service. Police graduates assigned in component cities were rated higher than those assigned in the urbanized city. In terms of operational performance, police graduates were rated "very satisfactory," which means that performance is above standards. Of the three domains, investigation rated the highest while traffic rated the lowest, although both are very satisfactory. The inverse assessment on traffic and investigation demonstrates that traffic operations were not an original function of the police, but due to the increased problems on traffic, the security function was transferred to the police. Patrol operation was also rated very satisfactory. PCOs rated the three domains higher than the ratings provided by PNCOs, although both rated police graduates very satisfactory. Consistent with competence, in terms of performance as to rank, patrolmen were rated higher than police corporals, and those who were assigned in component cities were also rated higher than those assigned in a highly urbanized city. There were no significant differences found when police graduates were grouped as to variables of rank and city class. There was a significant difference in the length of service, with those who served for a short period, registering the difference and implying the necessity of continuing education and training. A significant relationship was found between operational competence and performance. The findings of the study were used in the preparation of an enhanced training program for the police.

Conclusion. Training and continuing education are necessary for the police force in the exercise of their core functions of patrol, traffic, and investigation. Further, the stock of knowledge gained from graduation in a learning institution is acknowledged. Competence and performance are significantly 
related, as established by robust evidence. There are areas in the curriculum of training that need to be enhanced.

Practical Value of the Paper. The study significantly contributes to the studies on the necessity of training and continuing education. Likewise, it is one of the few studies that established a strong relationship between competence and performance and presents an enhanced training program to strengthen competence towards outstanding performance.

\section{References}

Basilio, R. D., Cueto, M. M., Dumas, E. M., Ortega, M. J. B., Zapata, J. D., \& Bautista, M. L. A. Job Satisfaction Levels of PNP Employees in a Provincial City.

Eduardo, J. P., \& Gabriel, A. G. (2017). Assessing the leadership skills of the chiefs of police in the towns of Nueva Ecija, Philippines: A dichotomy between managerial competence and decision making ability. Open Journal of Leadership, 6(4), 142-159.

Gomes Nascimento, T., Lucas de Souza, E. C., \& Adaid-Castro, B. G. (2020). Professional competences scale for police officers: evidence of psychometric adequacy. RAP: Revista Brasileira de Administração Pública, 54(1).

Inasoria, R. (2014). Effects of Profile, Religiosity and Job Attitude on the Job Performance of the Philippine National Police: The Case of Bulacan Province. Asia Pacific Journal of Multidisciplinary Research, 2(5), 22-32.

Laru-an, N. G., \& Beup, H. T. (2015). Level of Effectiveness of Community Policing. International Journal of Scientific and Research Publications, 5(2).

Lokesh, L., Patra, S., \& Venkatesan, S. (2016). Job satisfaction among police personnel: a socio-demographic study. Global Journal of Interdisciplinary Social Sciences, 4(5), 56-62.

Schaveling, J., Blaauw, S., \& van Montfort, K. (2017). Predictors of group performance in a police criminal investigation department: the role of gender homogeneity, leadership and team characteristics. Journal of Police and Criminal Psychology, 32(4), 358-368.

Tengpongsthorn, W. (2017). Factors affecting the effectiveness of police performance in Metropolitan Police Bureau. Kasetsart Journal of Social Sciences, 38(1), 39-44.

\section{Correspondence:}

Jimmy P. Laguyo [j_laguyo@yahoo.com]

https://orcid.org/0000-0002-8073-7189 